(c) 2018

\title{
Scientific-and-methodical maintenance of protection of lands of agricultural assignment as a precondition for sustainable development of agribusiness industry of Ukraine
}

\author{
Kaminskyi V., Dr. of Agr. Sci. academician \\ Shevchenko I., Kolomiiets $\mathrm{L}, \mathrm{PhD}$ in agriculture \\ NSC "Institut zemlerobstva of NAAS"
}

The purpose. Analysis of scientific-and-methodological maintenance of measures on protection and intelligent use of lands of agricultural assignment. Methods. System justification of scientific-andmethodological bases of nature of soil-ecological crisis phenomena in land-use and protection of lands of agricultural assignment against degradation processes. Results. Theoretical-and-methodological and application aspects of measures on ecological-and-economic regulation of use of land-resource potential in conditions of aggravation of ecological crisis in agrarian sector of the state are justified. Conclusions. Strategic priorities of heightening efficiency of use of potential of lands of agricultural assignment in the system of euro integration priorities of the state on the basis of heightening competitive strength and implementation of innovations specified.

Key words: degradation of lands, lands of agricultural assignment, land-resource potential, euro integration policy, protection of lands, control over land resources.

The Constitution of Ukraine recognizes the land resource as the main national wealth that is under the special protection of the state. This recognition is primarily due to the irreplaceability of land as a natural resource.

In the development of constitutional provisions, the Law of Ukraine "On the Protection of Land" defines the basic principles of state policy in the field of land conservation and its rational use, which consist in ensuring the protection of land as the main national wealth of the Ukrainian people, priority of environmental safety requirements in the use of land as spatial the basis of natural resources and the main means of production, and most importantly in the normalization and systematic limitation of the excessive impact of agricultural activity $[1,2]$.

Hence, land protection, including agricultural purposes, is and should remain one of the priorities of state policy in the context of the chosen European vector of development of the country [3].

Along with this, the new edition of the Strategy of the State Environmental Policy until 2030 states that the state of land resources of Ukraine is close to the critical one.

At the same time, problems in the field of protection and rational use of land are largely due to the incomplete process of reforming land relations, land inventory, the automation of the system of state land cadastre, the imperfection of land management documentation and the lack of regulatory and legal support, the complete lack of measures for educational and educational work, low institutional capacity of the relevant executive authorities [4].

The purpose of the research - Is to carry out an analysis of modern scientific approaches to the protection of agricultural land from the effects of degradation processes under market conditions of farming.

Research methods. The theoretical basis is the position of the economy of nature management, sustainable development. The methodological basis of the research is the fundamental principles and principles of the modern concept of sustainable and ecologically safe development.

Research results. In Ukraine, the problem of land protection was particularly aggravated with the onset of the reform of land relations, which was mainly aimed at denationalization and redistribution of land. Until 
1990, land protection was a priority, with nationwide support, and agricultural producers practically carried out a whole range of soil protection works. Since the first years of Ukraine's independence, the situation in the field of land protection has changed dramatically, especially this negative dynamics is noticeably observed with regard to the introduction of hydrotechnical structures, which are intended for the capture, collection and removal of surface runoff of atmospheric precipitation in order to reduce the risks of erosion processes. Thus, the construction of anti-erosion shafts, ditch shafts in 1995 made a total length of 135.2 $\mathrm{km}$, in $2005-3.6 \mathrm{~km}$, in $2011-2.9 \mathrm{~km}$. In 1995, construction of anti-erosion ponds (hard drives) was constructed with a total area of 177 hectares, in 2005 - 7 hectares, and in 2011 - 5.7 hectares. Reclamation of disturbed lands in 1990 was made on an area of 19.2 hectares, in $1995-8.4$ thousand hectares, in 2000 - 3.7 thousand hectares, and in 2011 - 0.6 thousand hectares, tabl.1 [5].

Table 1. Dynamics of implementation of measures for the protection of land

\begin{tabular}{|l|l|l|l|l|l|}
\hline & $\mathbf{1 9 9 5}$ & $\mathbf{2 0 0 0}$ & $\mathbf{2 0 0 5}$ & $\mathbf{2 0 1 0}$ & $\mathbf{2 0 1 1}$ \\
\hline $\begin{array}{l}\text { Construction of anti-erosion } \\
\text { hydrotechnical structures }\end{array}$ & & & & & \\
\hline shafts, shafts, ditches, km & 135,2 & 9,3 & 3,6 & 4,1 & 2,9 \\
\hline shaft-terraces, km & 5,4 & 10,9 & 6,6 & 0 & 0 \\
\hline road rollers, km & 16,2 & 2,2 & 1,1 & 0,1 & 0,2 \\
\hline $\begin{array}{l}\text { anti-erosion rates (hard disk } \\
\text { drains), ha }\end{array}$ & 177,0 & 24,0 & 7,0 & 6,6 & 6,7 \\
\hline pumping stations, pcs. & 51,0 & 18,0 & 2,0 & 12 & 8,0 \\
\hline shore protection, km of highly degraded & 1,0 & 4,7 & 3,9 & 4,3 & 7,1 \\
\hline $\begin{array}{l}\text { Fixing of } \\
\text { and contaminated with } \\
\text { harmful substances of arable } \\
\text { land, ha }\end{array}$ & 12785,0 & 14974,0 & 6341,5 & 1015,2 & 1383,0 \\
\hline $\begin{array}{l}\text { Reclamation of disturbed } \\
\text { lands, ths ha }\end{array}$ & 8,4 & 3,7 & 2,1 & 0,5 & 0,6 \\
\hline
\end{tabular}

*according to the State Geocadaster

In recent years, not enough to address the problems of rational use and land conservation, there remains a mechanism for combining measures of economic incentives and legal responsibility in the field of land protection through the implementation of an effective land management [Fig. 1].

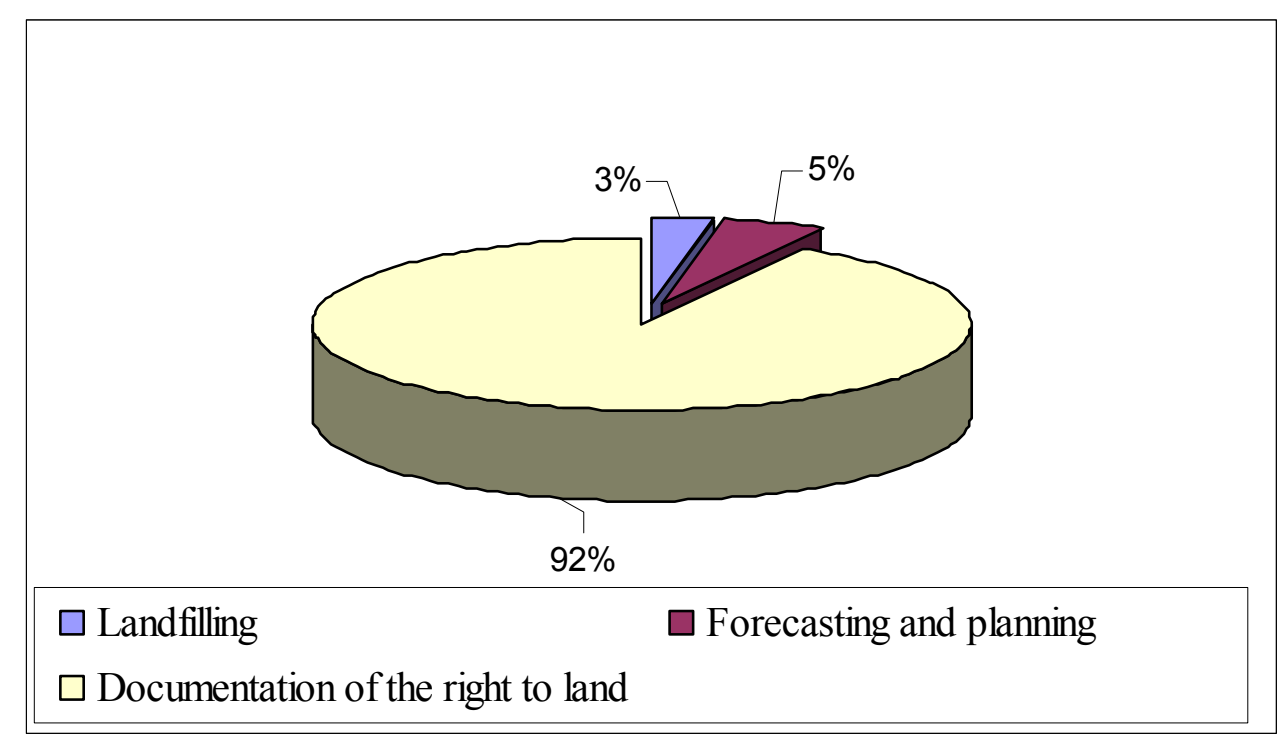

Fig. 1. The relevance of documentation on land management in the areas of land management, according to the State Geocodraw 
Significant transformations that took place during the land reform led to a violation of the structure of land, non-compliance with crop rotation, forms of agricultural production and, as a result, reduced the use of land resources.

One of the most negative consequences of the reformation of land relations was the decomposition of a significant part of degraded and unproductive land without taking into account the ecological component for the suspension of soil fertility loss processes, deceleration of deflation and water erosion.

The latter among these is the most significant factor in reducing the productivity of land and the growth of degradation of agricultural landscapes. The total area of agricultural lands affected by water erosion is 13.3 million. of hectares (32\%), including 10.6 million hectares of arable land. Among the eroded lands there are over 4.5 million hectares with medium and strongly washed soils, including 68 thousand hectares, which completely lost the humus horizon.

In the world, the processes of water and wind erosion are the most important among processes of degradation: $56 \%$ and $28 \%$ respectively. In Ukraine annually from 300 to 600 million tons of soil is lost from erosion. With products of erosion, 10-15 mlrd tons of humus, 0,3-0,9 million tons of nitrogen, 700900 thousand tons of phosphorus, 6-12 million tons of potassium, which is much more than that made with fertilizers, is carried out. Intensively developing processes of linear erosion and erratic formation. The area of ravines is more than 140 thousand hectares, and their number exceeds the limit of 500 thousand. Wind erosion systematically exposed more than 9 million hectares of land, and dust storms about 20 million hectares. Total annual losses of net profit amounted to 25-30 billion hryvnia.

The fundamental transformations in the system of land relations that take place in Ukraine in the conditions of decentralization of territorial development management and the expansion of powers of local self-government bodies, as well as the change of landmarks in the organization of land use and resource use of the country, require the formation of an effective system for increasing the efficiency of state regulation of land relations and land use management, improvement of instruments for further regulation of land relations between the state, regional and local euims territorial communities and scientific institutions that carry out scientific and methodological support for measures for the protection and rational use of land resources in order to create favorable conditions for the sustainable development of agricultural land use.

During more than one hundred years of its functioning, the research of scientists of the NSC "Institute of Agriculture of the NAAS" was focused on addressing the problems of the protection and rational use of agricultural land.

In particular, the Institute of Agriculture of the National Academy of Sciences in collaboration with other scientific institutions of the National Academy of Agrarian Sciences developed a soil protection and contouring-reclamation system of agriculture, the main provisions of which were adopted under the basic and recommended by the Government of Ukraine (Resolution of the Council of Ministers of the USSR dated 08.05.1990, No. 107) production. In pursuance of the resolution, the main components of the soil protection contour-reclamation system of agriculture were designed and implemented on an area of about 3.5 million hectares.

NSC "Institute of Agriculture of NAAS" has accumulated considerable research potential in the study of the effectiveness of soil protection technologies for soil cultivation, namely: the identification of mechanisms for the formation of anti-erosion stability and the establishment of ways to optimize the fertility of chernozem typical blown soils for the long-term maintenance of soil protection technologies for growing crops.

An integral part of the complex of anti-erosion measures aimed at controlling surface runoff (detainment or safe discharge) are hydraulic engineering anti-erosion structures, which are one of the most complex links in the system of contouring-reclamation agriculture for design, construction and operation. This block of soil protection measures was and remains the most material and capitalintensive.

The long-term researches have established that the only alternative to creation of complex capital-cost water-retaining and spillway structures on the cultivated strength lands can be only a complex of agro- 
technical, phyto-melioration and forest-melioration measures, which involves the application of groundprotecting anti-erosion technologies of growing crops, cutting and afforestation of power lands with a steepness of more than 3-5 degrees, creating on them natural forage lands, recreational and protected areas.

NSC "IZ NAAN" extended and in-depth scientific researches on the development of the main parts of groundwater protection landscape systems of agriculture, by adjusting and clarifying the main methodological provisions and approaches to the organization of agricultural enterprises territories with a view to systematically optimizing the use of natural and material and technical resources, differentiated adaptation of land use to soil - Landscape and climatic factors, as well as regulation of gradation processes.

The conducted calculations revealed that the introduction of a soil-protecting adaptive-landscape system of agriculture significantly increases the parameters of soil protection efficiency within the land use of agricultural enterprises.

At the same time, the loss of the fertile soil layer in general from the territory of land use is reduced by 1.8 times, which contributes to increasing the economic efficiency and environmental safety of the use of agrarian landscapes.

The scientists of the NSC "Institute of Agriculture of the NAAN" have also worked out conceptual provisions on the main criteria and indicators that determine the need for removal from intensive cultivation for the conservation of degraded, unproductive and other lands. These provisions include legal grounds, regional features of the use of eroded lands, economic incentives for conservation measures for degraded land [5-8].

With the purpose of rational use and protection of lands, creation of a favorable economic environment, increase of productivity of agricultural crops, provision of ecological and food security of the state there is a need for further development of effective land management, solution of existing land use problems on the basis of planning of the legal regime of land use by adopting appropriate normative legal documents, including the Law of Ukraine "On Crop rotation," as a component of systems and planning of the use and protection of land and land management (scientists NSC "IZ NAAN" are the developers of the draft normative legal act).

In order to minimize and achieve a neutral level of degradation processes, increase the efficiency of use of agricultural land potential, development of highly effective competitive agricultural production in the Kiev region, balanced development of rural areas, provision of ecological and food safety of the NSC "Institute of Agriculture of the NAAS" as the Scientific and Methodological Center "Agriculture" in Ukraine and the Center of scientific support of agricultural production Kyivs This area will provide scientific support and implementation of the main provisions of the "Integrated Program for the rational use and protection of land in the Kiev region" in the context of the "Basic Principles (Strategy) of the State Environmental Policy of Ukraine for the period up to 2030" in the direction of the transition to a territorial self-regulatory system for the management of rural development .

\section{Conclusions}

In today's socio-economic conditions, land reform, land conservation and its rational use are gaining increasing importance, first of all, in view of the need to increase the productivity and competitiveness of the agricultural sector in the national economy, as well as the requirements of the Framework of the Soil of the European Parliament and the Council Europe.

The issue of elaboration of the scientific basis for the organization of the territory of modern land use, designing and mastering of the newest ground protection adaptive-landscape systems of agriculture, introduction of measures on ecological and economic regulation of the use of land-resource potential in the conditions of aggravation of the ecological crisis in the agrarian sector should become one of the most important directions of state policy in field of protection of agricultural lands. 


\section{Bibliography}

1. Law of Ukraine "On Land Management": adopted on May 22, 2003, No. 858-IV Information from the Verkhovna Rada of Ukraine (2003). №36. P. 282.

2. Law of Ukraine "On the Protection of Land": adopted on June 19, 2003 No. 962-IV Information from the Verkhovna Rada of Ukraine (2003). №39. - P. 349.

3. Draft Framework of the Soil Directive of the European Parliament and of the Council of Europe. Brussels, September 22.09.2006. COM (2006) 232. - 2006/0086 (SAD).

4. Law of Ukraine "On Amendments to the Law of Ukraine" On the Basic Principles (Strategy) of the State Environmental Policy of Ukraine for the Period until 2020": adopted on 21.12.2020 року № 2818-VI Information from the Verkhovna Rada of Ukraine (2011). №26. P. 218.

5. Kaminsky V.F., Shevchenko V.F., (2013) Experience of organization and effective use of land in erosion-hazardous agrolandscapes of the Forest-Steppe zone. The guide of Ukrainian grain growers. T.1. P.10-11.

6. Kaminsky V.F., Shevchenko I.P., Kolomiets L.P. (2016) Theoretical and methodological support for optimization of land use of rural territories in the context of the implementation of the euro integration policy: scientific support and implementation efficiency. Interagency thematic scientific collection "Agriculture". №2.

7. Kaminsky V.F., Shevchenko I.P., Kolomiets L.P. (2016). Scientific and methodological principles of land resources management for adaptive land management Interagency thematic scientific collection "Agriculture". №1 (90).

8. Kaminsky V.F., Shevchenko I.P., Kolomiets L.P. (2017). Land management of the protection and rational use of agricultural land land use. Interagency thematic scientific collection "Agriculture". № 2.

9. National Action Plan to Combat Land degradation and Desertification. Order of the Kobinet of Ministers of Ukraine dated March 30, 2016 №271-p.

10. Cabinet of Ministers Resolution "Some Issues of Improving Governance in the Use and Protection of Agricultural Properties of State Owned Land". "Government Courie" of 07.06.2017. №413 [electronic resource]: Ukrainian legislation. - Access mode: https: |//zakon.rada.gov.ua/laws/show/413-2017-n.

11. Hazarika M.K. Honda H. Estimation of Soil Erosion using Remote Sensing and GIS. Its Valuation \& Economic Implications on Agricultural Productions. The 10th International Soil Conservation Organization Meeting at Purdue University and the USDA-ARS Soil Erosion Research Laboratory. 2001. P. 1090-1091. 